\title{
Description of the male of Aillutticus rotundus Galiano and five new species of Aillutticus Galiano from Brazil (Araneae, Salticidae, Sitticinae)
}

\author{
Gustavo R. S. Ruiz \& Antonio D. Brescovit \\ Laboratório de Artrópodes, Instituto Butantan. Avenida Vital Brazil 1500, 05503-900 São Paulo, São Paulo, Brasil. \\ E-mail: gustavoruiz86@hotmail.com; adbresc@terra.com.br
}

\begin{abstract}
The male of Aillutticus rotundus Galiano, 1987 is described for the first time and new records are presented from the states of Acre, Mato Grosso do Sul and São Paulo, Brazil. In addition, five new species of this genus are described from Brazil: $A$. knysakae sp. nov. from the states of Minas Gerais, Piauí and Tocantins, $A$. montanus sp. nov. from the state of Minas Gerais, $A$. raizeri sp. nov. from the state of Mato Grosso do Sul, $A$. soteropolitano sp. nov. from the state of Bahia, and A. viripotens sp. nov. from the states of Rondônia and Tocantins. KEY WORDS. Spiders; systematics; taxonomy.
\end{abstract}

\begin{abstract}
RESUMO. Descrição do macho de Aillutticus rotundus Galiano e cinco espécies novas de Aillutticus Galiano do Brasil (Araneae, Salticidae, Sitticinae). O macho de Aillutticus rotundus Galiano, 1987 é descrito pela primeira vez e novos registros são apresentados para os estados do Acre, Mato Grosso do Sul e São Paulo. Além disso, são descritas cinco espécies novas deste gênero para o Brasil: A. knysakae sp. nov. de Minas Gerais, Piauí e Tocantins, A. montanus sp. nov. de Minas Gerais, A. raizeri sp. nov. do Mato Grosso do Sul, A. soteropolitano sp. nov. da Bahia e A. viripotens sp. nov. de Rondônia e Tocantins.

PALAVRAS-CHAVE. Aranhas; sistemática; taxonomia.
\end{abstract}

The genus Aillutticus Galiano, 1987 was proposed to include the type species A. nitens Galiano, 1987 from Argentina and Brazil, A. pinquidor Galiano, 1987 from Argentina, and $A$. rotundus Galiano, 1987 from Brazil. According to GALIANO (1987: $157,159)$, species of this genus were similar to those of the Sitticus/Attulus complex (see Platnick 2006 under Sitticus Simon for comments) in their general appearance, from which they differed by having more complex structures in the male palp: tibia with a retrolateral projection limited ventrally by a stout apophysis and externally by a row of strong, spine-like setae, cymbium large when compared to body size and bulb discoidal with a distal prolateral embolus which is short, stout and heavily sclerotized. Nevertheless, the Neotropical species described in, or transferred to Sitticus Simon seem not to be congeners of the species of the Holarctic genus Sitticus sensu strictu, including the Palearctic type species S. terebratus (Clerck, 1757), thus the need of a revision of the Neotropical species of the genus.

After the description of Aillutticus, considerable improvement was achieved on the taxonomy of Neotropical sitticines (e.g. Galiano 1989, 1991a, b, Ruiz \& Brescovit 2005, 2006) and with the description of the sitticine genera Nosferattus Ruiz \& Brescovit, 2005, Capeta Ruiz \& Brescovit, 2005, Amatorculus Ruiz \& Brescovit, 2005, and Gavarilla Ruiz \& Brescovit, 2006 (RuIz \& Brescovit 2005, 2006), all morphologically more similar to
Aillutticus than Sitticus, it became more difficult to suggest a sister-group for Aillutticus without a phylogenetic analysis.

In this paper the genus is divided into two morphological groups, the nitens group and the rotundus group. The nitens group includes $A$. nitens and $A$. pinquidor, both of which present well developed tibial spine-like setae in the male palp (see GaLiano 1987, figs 3-8). These species have also a poorly developed RTA in the male palp (treated just as "retrolateral tibial projection" by GALIANO 1987), short digitiform glands, a short longitudinal septum and membranous, soft, translucent structures in the female epigynum (see Galiano 1987, figs 9-13, 1516). The rotundus group includes all the species herein described (including A. rotundus Galiano) and is characterized by the reduction, both in size and number, of the tibial spine-like setae of the male palp, becoming few and/or slender. In addition, species included in this group present a well developed RTA in the male palp and elongated digitiform glands and a long longitudinal ventral septum in the female epigynum.

The females of the rotundus group are especially difficult to separate mainly because the epigyna are very simple and ventral areas may vary in the degree of sclerotinization. The disruptive coloration pattern is the same in all species and they are all about the same size. Sometimes clues are provided by the form of the spermathecae and digitiform glands, but even these structures may vary within a single species. 
Even males of Aillutticus can sometimes be difficult to identify, as pointed out by GaLIano (1987: 162), after examining a pair of samples from Pará and São Paulo, collected by Moenkhaus and deposited in the Milwaukee Public Museum, doubtfully assigned to A. nitens. According to GaLIANo (1987), the tibial spinelike setae of the males from São Paulo were broken and lost, and the single male from Pará had a fringe of stout, long hairs on the ventral and lateral sides of the patellae and tibiae of the first legs.

Galiano (1987: 160) presented very informative notes on the natural history of species of this genus, generally cryptically present in areas covered with gravel. All the Brazilian material examined in this study was collected in pitfall traps. Most of it comes from the "Cerrado" region (Savannah), a Brazilian phytogeographic biome characterized by a regular and moderate dry season (RIzzinI 1997). Even in cases when the material comes from areas covered by forests, specimens were collected in deforested places, where the sandy soil is exposed, as pointed out for the type locality of $A$. rotundus (GALIANO 1987: 164).

\section{MATERIAL AND METHODS}

The material examined is deposited in the collections of the following institutions (abbreviation and curators in parentheses): Laboratório de Artrópodes, Instituto Butantan, São Paulo (IBSP, A.D. Brescovit); Museu de Zoologia da Universidade de São Paulo, São Paulo (MZSP, R. Pinto da Rocha); Laboratório de Artrópodes Peçonhentos, Universidade Federal da Bahia, Salvador (UFBA, T.K. Brazil) and Museu Nacional do Rio de Janeiro, Rio de Janeiro (MNRJ, A.B. Kury). All measurements are given in millimeters. The abbreviations used throughout the text are: (RTA) retrolateral tibial apophysis, (VTA) ventral tibial apophysis, (AME) anterior median eyes, (ALE) anterior lateral eyes, (PLE) posterior lateral eyes, (d) dorsal, (p) prolateral, (r) retrolateral, (v) ventral, (pr) proximal, (di) distal.

\section{Aillutticus rotundus Galiano}

Figs 1-2

Aillutticus rotundus GaLIANo 1987: 164, figs 14, 17 (Female holotype from BrazIL, Amazonas: Reserva Ducke, VIII.1971, M.E. Galiano leg., deposited in the MNRJ 2257, examined); Platnick 2006.

Diagnosis. Males of Aillutticus rotundus Galiano resemble those of $A$. raizeri sp. nov. by the reduced embolus and similar VTA (Figs 1 and 11), but are distinguished by the elongated tegulum and the presence of a single spine-like seta on the dorsal branch of the RTA of the male palp (Fig. 1). The females are distinguished from those of $A$. raizeri by the longer digitiform glands (see Galiano 1987, fig. 17).

Description. Total length: 2.85. Carapace dark brown, 1.60 long, 1.25 wide, 0.95 high, laterally covered with white hairs. Ocular quadrangle 0.75 long. Anterior eye row 1.15 wide and posterior 1.05 wide. Cephalic region laterally delimited by white hairs. Clypeus with dense white hairs. Chelicera yellow, with 5 teeth on promargin. Endite pale yellow. Labium and sternum light brown. Palp yellow; embolus slightly curved; RTA with two branches, one spine-like seta on the dorsal branch; VTA squared (Figs 1-2). Legs $412=3$ light brown, with dark brown rings. Length of femur: I 0.80, II 0.75, III 0.75, IV 1.35; patella + tibia: I 0.87 , II 0.80 , III 0.75 , IV 1.45 ; metatarsus + tarsus: I 0.80, II 0.80, III 0.85, IV 1.15. Abdomen variegated with pale yellow and dark brown, dorsally covered by a dark brown scutum. Spinnerets yellow.

Female. Described by Galiano (1987: 164, figs 14, 17).

Material examined. Brazil, Acre: Senador Guiomard (Reserva Extrativista de Catuaba), 14 males and 2 females, VIIX.2001, E.F. Morato leg. (IBSP 51560-51574); Mato Grosso do Sul: Ivinhema, 31 males and 5 females, 07.X.2004, K. Anjos leg. (IBSP 44446, 51575-51576, 51669, 53754-53776); Brasilândia (Usina Hidrelétrica Sérgio Motta), 1 male, 31.VII-07.VIII.2000, Equipe IBSP leg. (IBSP 30837); 1 female, 16-24.VII.2000, Equipe IBSP leg. (IBSP 30668); São Paulo: Itirapina (Estação Ecológica de Itirapina), 130 males and 34 females, 2001-2002, C.R. Bertim leg. (IBSP 44675-44758, 44872-44908).

Distribution. Known from the states of Acre, Amazonas, Mato Grosso do Sul e São Paulo (Brazil).

\section{Aillutticus knysakae sp. nov. Figs 3-6}

Types. Male holotype from BraziL, Tocantins: Palmas (Taquaralto, Jardim Taquari), 4-10.XI.2002, I. Knysak \& R. Martins leg. (IBSP 51437); Paratypes: one female from BRAZIL, Tocantins: Palmas (Área Residencial Sudoeste 307), 2-9.VII.2002, I. Knysak \& R. Martins leg. (IBSP 51442); one male from BrazIL, Tocantins: Porto Nacional (Ribeirão Água Suja), 18-22.IX.2000, I. Knysak, R. Martins \& G. Puorto leg. (IBSP 51459); one female from BrazIL, Tocantins: Porto Nacional, 2001 (IBSP 51465).

Etymology. The species is named in honour of Irene Knysak, one of the collectors of the holotype.

Diagnosis. Aillutticus knysakae sp. nov. differs from the remaining species of the genus by having a rectangular, transversally directed embolus in the male palp (Fig. 3) and elliptical spermathecae in the female epigynum (Fig. 6).

Description. Male. Total length: 2.65. Carapace light brown, 1.50 long, 1.15 wide, 0.85 high. Ocular quadrangle 0.75 long. Anterior eye row 1.05 wide and posterior 1.00 wide. Cephalic region dark brown, sparsely covered with white hairs; long brown hairs around the anterior eyes. Clypeus densely covered with white hairs. Chelicera light brown, with 5 teeth on promargin. Endite, labium and sternum light brown. Palp light brown, dorsal cymbium densely covered with white hairs; embolus rectangular, transversally directed; RTA with two short branches and only one spine-like seta on the dorsal branch; VTA conical (Figs 3-4). Legs 4132 yellow with brown rings, variegated with light brown. Length of femur: I 0.70, II 0.70, III 0.70, IV 1.30; patella + tibia: I 0.80, II 0.75, III 0.75, IV 1.40; metatarsus + tarsus: I 0.75, II 0.70, III 0.75, IV 1.10. Abdomen cream colored, dorsally covered by a smooth dark brown scutum, laterally and ventrally variegated with dark brown. 




Figures 1-6. (1-2) Aillutticus rotundus: (1) male palp, ventral view; (2) retrolateral view; (3-6) Aillutticus knysakae sp. nov.: (3) male palp, ventral view; (4) retrolateral view; (5) epigynum, ventral view; (6) dorsal view. (db) Dorsal branch of RTA, (dg) digitiform gland, (rta) retrolateral tibial apophysis, (sls) spine-like seta, $(\mathrm{vb})$ ventral branch of RTA, (vta) ventral tibial apophysis. Scale lines: $0.25 \mathrm{~mm}$.

Anterior spinnerets yellow, posterior brown.

Female. Total length: 3.20. Carapace light brown, laterally variegated, 1.65 long, 1.30 wide, 0.95 high. Ocular quadrangle 0.80 long. Anterior eye row 1.17 wide and posterior 1.12 wide. Carapace with a longitudinal median dark brown stripe extending from between the PLE to the posterior edge. Cephalic region dark brown. Clypeus with few white hairs. Chelicera yellow, with five teeth on promargin. Endite, labium and ster-

Revista Brasileira de Zoologia 23 (2): 529-536, junho 2006 
num yellow. Palp yellow. Legs 4312 yellow, with dark brown rings. Length of femur: I 0.75, II 0.75, III 0.80, IV 1.50; patella + tibia: I 0.92, II 0.85, III 0.85, IV 1.62; metatarsus + tarsus: I 0.70, II 0.70, III 0.85 , IV 1.30. Abdomen dorsally light brown, with two pairs of cream spots and chevrons extending from the middle to the posterior edge of the abdomen. Epigynum with an U-shaped atrium and a longitudinal median narrow septum; internally with elliptical spermathecae and long digitiform glands with their ends close to the spermathecae (Figs 5-6). Spinnerets as in the male.

Variation. Ten males: total length: 2.60-3.65; carapace length: 1.30-1.70. Ten females: total length: 2.65-3.30; carapace length: 1.35-1.70.

Additional material examined. BraziL, Piauí: Teresina (Campus da Empresa Brasileira de Pesquisa Agropecuária), 1 male, 18.V.2005, O.S. Rocha leg. (IBSP 53752); 2 males and 1 female, 1.VI.2005, O.S. Rocha leg. (IBSP 53753); Tocantins: Brejinho Nazaré, 4 males and 1 female, 16.VIII.2001 (IBSP 51428-51431); Ipueiras, 4 males, 25.X-01.XI.2001 (IBSP 51449-51452); Lageado, 12 males and 1 female, 2001 (IBSP 51469-51477); 5 females, 18.V.2001 (IBSP 51432-51433; 51443-51445); 12 males and 2 females, 4.VI.2001 (IBSP 51478-51487); Palmas, 6 males and 1 female, 20-24.XI.2000 (IBSP 51415-51421); 2 males and 1 female, 2001 (IBSP 51446-51448); (Fazenda Brejo Redondo) 1 male and 1 female, 11-19.VI.2001 (IBSP 51434-51435); (ARSO 307) 3 males, 2-9.VII.2002 (IBSP 51439-51441); (Taquaralto, Jardim Taquari) 1 male, 4-10.XI.2002 (IBSP 51437); Porto Nacional, 1 male, 2000 (IBSP 51438); 1 male and 4 females, 2001 (IBSP 5146651468); 1 male, 5.II.2001 (IBSP 51436); 2 males, 18-23.III.2001 (IBSP 51424-51425); 3 males and 2 females, 16.VIII.2001 (IBSP 51422-51423; 51426-51427), all collected by I. Knysak \& R. Martins; (Ribeirão Água Suja) 13 males and 2 females, 1822.IX.2000, I. Knysak, R. Martins \& G. Puorto leg. (IBSP 5145351458, 51460-51464); Minas Gerais: Santana do Riacho, Parque Nacional da Serra do Cipó, 6 males, 07-14.X.2002, Equipe Biota leg. (IBSP 51496, 51498, 51501, 51505, 51507, 51518).

Distribution. Known from the states of Minas Gerais, Piauí and Tocantins (Brazil).

\section{Aillutticus montanus sp. nov.} Figs 7-10

Types. Male holotype from BraziL, Minas Gerais: Santana do Riacho (Parque Nacional da Serra do Cipó, $19^{\circ} 15^{\prime} \mathrm{S}, 43^{\circ} 31^{\prime} \mathrm{W}$ ), 07-14.X.2002, Equipe Biota leg. (IBSP 51504); Paratypes: three males and two females with the same data as holotype (IBSP 51514, MZSP).

Etymology. The species name is a Latin adjective and means "found on the montains". It refers to the type locality.

Diagnosis. Aillutticus montanus sp. nov. differs from the remaining species of the genus by having a distally dilated embolus in the male palp (Fig. 7) and an atrium wider than long in the female epigynum (Fig. 9).

Description. Male. Total length: 3.80. Carapace dark brown, 1.80 long, 1.40 wide, 0.95 high. Ocular quadrangle 0.85 long. Anterior eye row 1.25 wide and posterior 1.20 wide. Cephalic region with a longitudinal stripe of white hairs. Clypeus densely covered with white hairs. Chelicera yellow, with 5 teeth on promargin. Endite and labium yellow, sternum yellow variegated with brown. Palp with a distal dilated embolus; RTA with two short branches and two spine-like setae on the dorsal branch; VTA long and sinuous (Figs 7-8). Legs 4123 yellow, slightly variegated with light brown. Length of femur: I 0.80, II 0.85, III 0.85, IV 1.55; patella + tibia: I 0.95, II 0.90, III 0.75, IV 1.55; metatarsus + tarsus: I 0.90, II 0.85, III 0.95, IV 1.30. Abdomen cream colored, dorsally covered by a anterior dark brown scutum. Spinnerets cream colored.

Female. Total length: 5.20. Carapace light brown, variegated with dark brown, 2.05 long, 1.65 wide, 1.10 high. Ocular quadrangle 0.97 long. Anterior eye row 1.35 wide and posterior 1.30 wide. Carapace with a wide longitudinal median dark brown stripe extending from between the PLE to the posterior edge, laterally covered with white hairs and dorsally with long brown hairs. Clypeus with white hairs. Chelicera yellow, with 4 teeth on promargin. Endite, labium and sternum yellow. Palp yellow. Legs 4132 yellow, with dark brown rings. Length of femur: I 0.95, II 0.95, III 0.95, IV 1.75; patella + tibia: I 1.15, II 1.05, III 1.00, IV 2.00; metatarsus + tarsus: I 0.92, II 0.92, III 1.05, IV 1.50. Abdomen cream colored, dorsally densely covered with brown hairs and with a pair of spots and slightly conspicuous chevrons. Epigynum with an U-shaped atrium, a short septum and sinuous posterior border; internally with small, spherical spermathecae and narrow, long digitiform glands, with their tips away from the spermathecae (Figs 9-10). Spinnerets as in the male.

Variation. Ten males: total length: 2.15-3.80; carapace length: 1.72-1.90. Three females: total length: 4.40-5.20; carapace length: 1.95-2.05.

Additional material examined. BraziL, Minas Gerais: Ouro Preto (Estação Ecológica do Tripuí), 5 males, 2000-2001, H.G.G. Souza leg. (IBSP 51396-51399); Santana do Riacho (Parque Nacional da Serra do Cipó), 29 males and 1 female, 0714.X.2002, Equipe Biota leg. (IBSP 51488-51495, 51497, 5149951500, 51502-51503, 51506, 51508-51513, 51516).

Distribution. Known only from the state of Minas Gerais (Brazil).

\section{Aillutticus raizeri sp. nov.}

\section{Figs 11-14}

Types. Male holotype from BRAzIL, Mato Grosso do Sul: Corumbá (Passo do Lontra), VI.1998-XI.1999, J. Raizer leg. (IBSP 51541); Paratypes: one male and two females with the same data as holotype (IBSP 51549; 51552).

Etymology. The species is named in honour of Josué Raizer, the collector of the holotype.

Diagnosis. Males of Aillutticus raizeri sp. nov. resemble those of $A$. rotundus Galiano, 1987 by the reduced embolus and similar VTA (Figs 11, 1), but can be distinguished by having a circular tegulum and two spine-like setae on the dorsal branch 

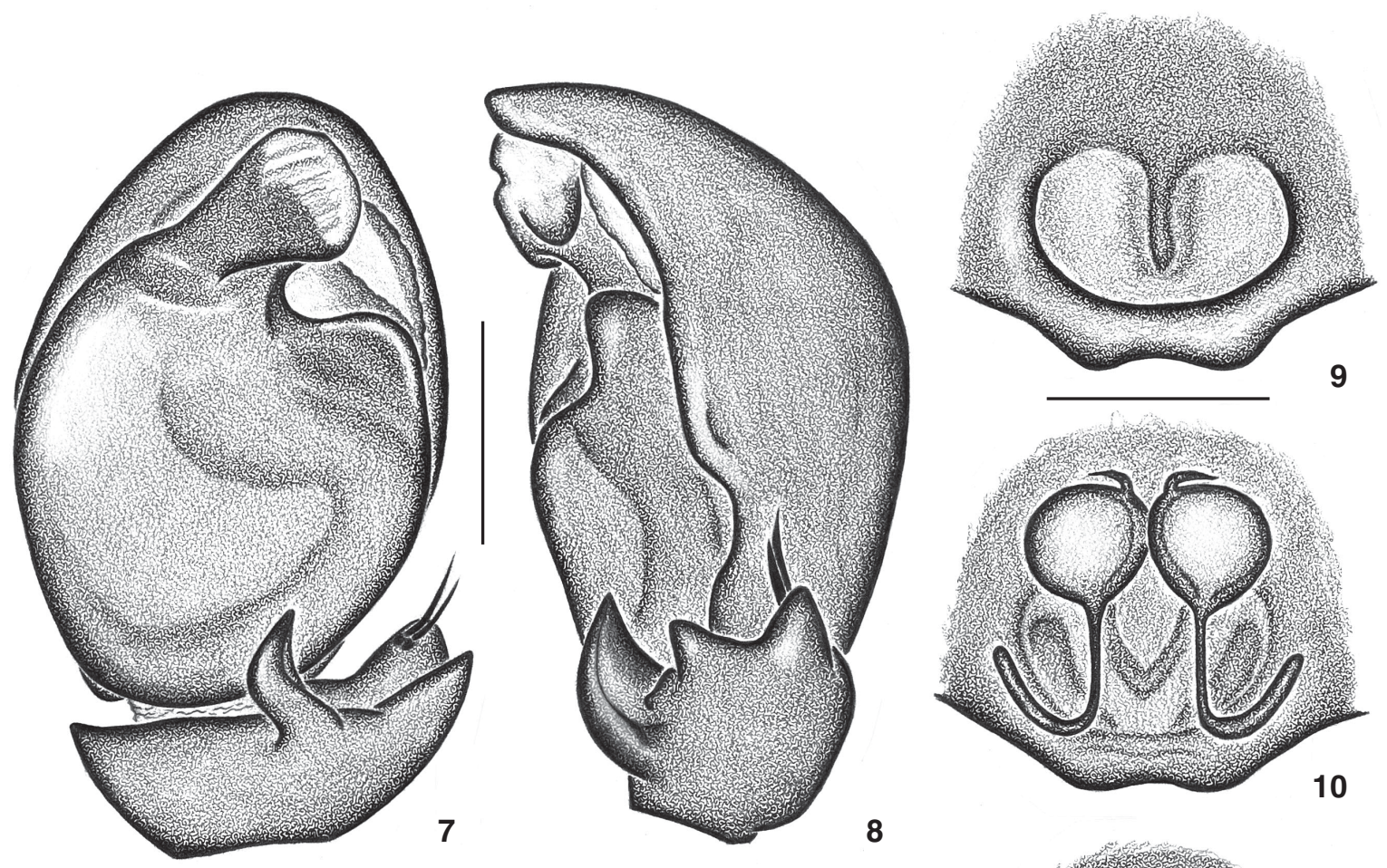

8
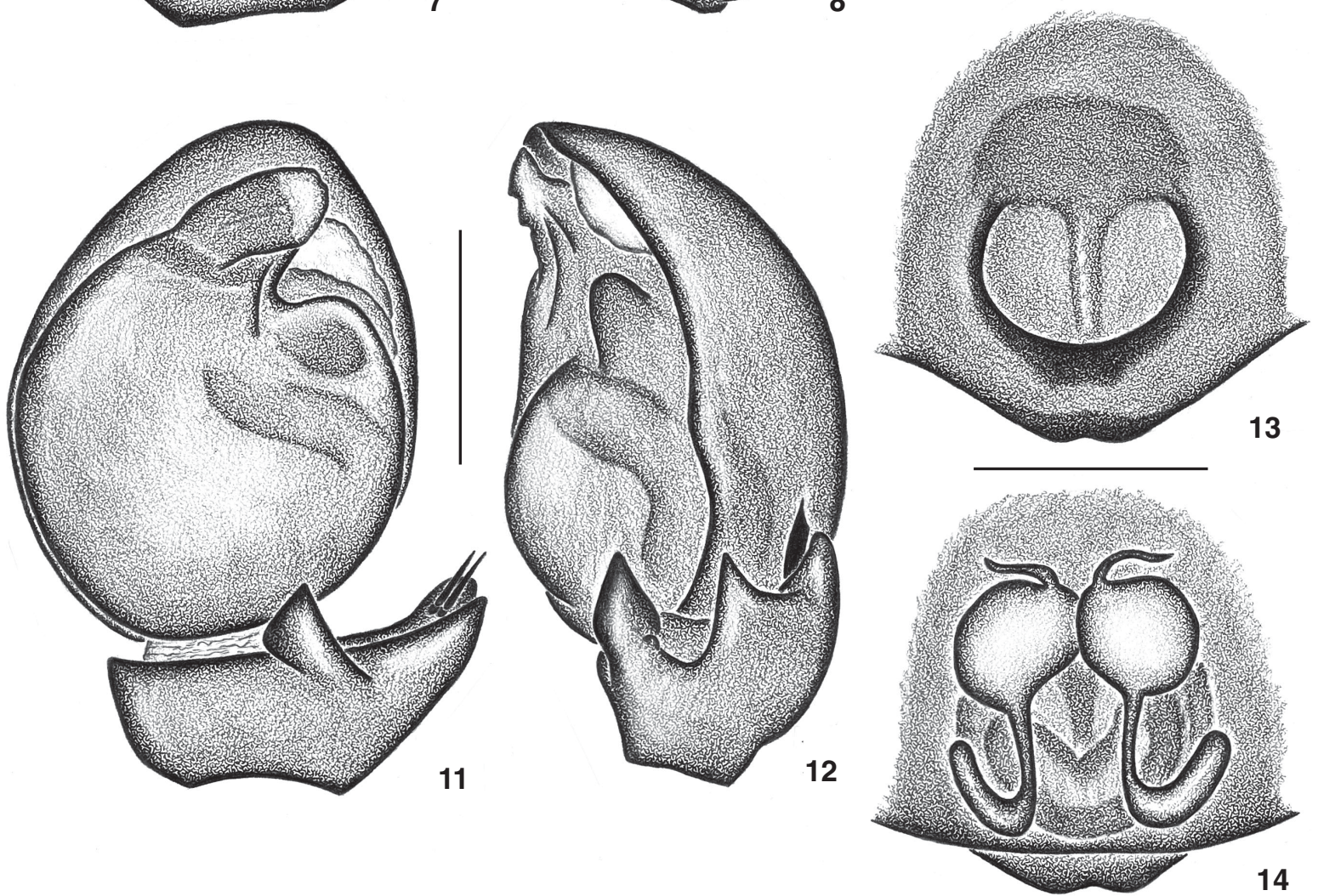

Figures 7-14. (7-10) Aillutticus montanus sp. nov.: (7) male palp, ventral view; (8) retrolateral view; (9) epigynum, ventral view; (10) dorsal view; (11-14) Aillutticus raizeri sp. nov.: (11) male palp, ventral view; (12) retrolateral view; (13) epigynum, ventral view; (14) dorsal view. Scale lines: $0.25 \mathrm{~mm}$. 
of the RTA of the male palp (Fig. 11). The females can be distinguished from those of $A$. rotundus by the shorter digitiform glands of the epigynum (Fig. 14).

Description. Male. Total length: 2.75. Carapace light brown variegated with dark brown, 1.47 long, 1.15 wide, 0.87 high, with a wide longitudinal dark brown stripe extending from between the PLE to the posterior edge of the carapace, laterally covered with white hairs. Ocular quadrangle 0.75 long. Anterior eye row 1.07 wide and posterior 1.02 wide. Cephalic region dark brown, with a narrow median stripe of white hairs. Clypeus with white hairs. Chelicera yellow, with 5 teeth on promargin. Endite, labium and sternum yellow. Palp yellow with dark brown rings; RTA with two short branches, two spinelike setae on the dorsal branch; VTA squared (Figs 11-12). Legs 4123 yellow, with dark brown rings. Length of femur: I 0.70, II 0.65, III 0.65, IV 1.20; patella + tibia: I 0.75, II 0.72, III 0.70, IV 1.30; metatarsus + tarsus: I 0.72 , II 0.75 , III 0.75 , IV 1.05. Abdomen dorsally dark brown, covered by a dark brown scutum and with two pairs of spots of white hairs, variegated laterally and ventrally. Anterior spinnerets yellow, posterior brown.

Female. Total length: 3.55. Carapace light brown variegated with dark brown, 1.75 long, 1.35 wide, 0.92 high, with a wide longitudinal dark brown stripe extending from between the PLE to the posterior edge of the carapace, laterally covered with white hairs. Ocular quadrangle 0.70 long. Anterior eye row 1.22 wide and posterior 1.15 wide. Cephalic region dark brown. Clypeus with few white hairs. Chelicera yellow, with 5 teeth on promargin. Endite, labium and sternum yellow. Palp yellow. Legs 4123 yellow, with dark brown rings. Length of femur: I 0.75, II 0.80, III 0.80, IV 1.42; patella + tibia: I 0.92, II 0.85, III 0.85, IV 1.60; metatarsus + tarsus: I 0.72 , II 0.72 , III 0.85 , IV 1.30. Abdomen dorsally dark brown with two pairs of spots of white hairs, variegated laterally and ventrally. Epigynum with an U-shape atrium and a long longitudinal septum; posterior border sulcated; internally with spherical spermathecae and long digitiform glands with very narrow bases, with their tips away from the spermathecae (Figs 13-14). Spinnerets as in the male.

Variation. Ten males: total length: 2.70-3.15; carapace length: 1.47-1.62. Ten females: total length: 3.25-4.00; carapace length: $1.65-1.82$.

Additional material examined. Brazil. Mato Grosso do Sul: Corumbá, Passo do Lontra, 8 males and 9 females, VI.1998-XI. 1999, J. Raizer leg. (IBSP 51542-51548, 51550-51551, 51553-51559).

Distribution. Known only from the state of Mato Grosso do Sul (Brazil).

\section{Aillutticus soteropolitano sp. nov. Figs 15-18}

Types. Male holotype from BraziL, Bahia: Salvador (Parque da Lagoa e Dunas do Abaeté), IV.2001, R. Smania leg. (IBSP 51540); Paratypes: two males and three females with the same data as holotype (IBSP 51532; 51533; 51539; UFBA).

Etymology. The species name is an adjective used to re- fer to people born in Salvador, the type locality.

Diagnosis. Aillutticus soteropolitano sp. nov. differs from the remaining species by having a well developed, stout RTA in the male palp (Fig. 15), inside of which there is a row of reduced setae that can only be seen in distal view, and by having very small spermathecae in the female epigynum (Fig. 18).

Description. Male. Total length: 2.70. Carapace light brown variegated with dark brown, 1.52 long, 1.20 wide, 0.90 high. Ocular quadrangle 0.80 long. Anterior eye row 1.10 wide and posterior 1.02 wide. Cephalic region dark brown, with a median longitudinal stripe of white hairs. Carapace laterally covered with white hairs. Clypeus densely covered with white hairs. Chelicera yellow, with 5 teeth on promargin. Endite yellow, labium and sternum light brown. Palp light brown, with dark brown rings; long embolus with translucent tip; RTA with two long and separated branches, four developed spine-like setae on the dorsal branch, one on the ventral branch and a row of small setae on the inner side of the RTA, joining the two branches (only seen in distal view); VTA long (Figs 15-16). Legs 4123 light brown, with dark brown rings. Length of femur: I 0.75 , II 0.75 , III 0.75 , IV 1.30 ; patella + tibia: I 0.87, II 0.80, III 0.75, IV 1.40; metatarsus + tarsus: I 1.00, II 1.00, III 1.00, IV 1.10. Abdomen dorsally covered by a narrow dark brown scutum and dark brown hairs, laterally variegated and covered with white hairs, ventrally variegated with light and dark brown. Anterior spinnerets yellow, posterior brown.

Female. Total length: 3.35. Carapace light brown variegated with dark brown, 1.80 long, 1.35 wide, 1.00 high, laterally covered with white hairs. Ocular quadrangle 0.80 long. Anterior eye row 1.22 wide and posterior 1.15 wide. Cephalic region covered with brown hairs. Chelicera yellow, with 5 teeth on promargin. Endite, labium and sternum yellow. Palp yellow. Legs 4312 yellow, with dark brown rings. Length of femur: I 0.70, II 0.80, III 0.85, IV 1.55; patella + tibia: I 1.00, II 0.92, III 0.90, IV 1.75; metatarsus + tarsus: I 0.85, II 0.75, III 0.90, IV 1.30. Abdomen dorsally light brown, covered with dark brown hairs; dorsal spots little conspicuous; light brown laterally and ventrally. Epigynum with a small U-shaped atrium and long median septum; posterior border sinuous; internally with reduced spermathecae and long digitiform glands (Figs 17-18). Spinnerets as in the male.

Variation. Ten males: total length: 2.65-3.25; carapace length: 1.50-1.80. Nine females: total length: 2.70-4.25; carapace length: 1.72-1.90.

Additional material examined. Brazil. Bahia: Salvador, Parque da Lagoa e Dunas do Abaeté, 15 males and 8 females, IV.2001, R. Smania leg. (IBSP 51519-51529, 51531, 51535-51537; UFBA). Distribution. Known only from the state of Bahia (Brazil).

\section{Aillutticus viripotens sp. nov. Figs 19-22}

Types. Male holotype from BrAziL, Rondônia: Vilhena, IX.1999, M.C. Carvalho leg. (IBSP 51400); one male and two female paratypes with the same data as holotype (IBSP 51407; 



Figures 15-22. (15-18) Aillutticus soteropolitano sp. nov.: (15) male palp, ventral view; (16) retrolateral view; (17) epigynum, ventral view; (18) dorsal view; (19-22) Aillutticus viripotens sp. nov.: (19) male palp, ventral view; (20) retrolateral view; (21) epigynum, ventral view; (22) dorsal view. Scale lines: $0.25 \mathrm{~mm}$.

\section{$51413 ; 51414)$}

Etymology. The species name is a Latin adjective and means "powerful".

Diagnosis. Aillutticus viripotens sp. nov. resembles $A$. soteropolitano sp. nov. by the elongated embolus, but differs from this species by having a longer embolus in the male palp, with a median sclerotinized area on its tip (Fig. 19) and by having large, round spermathecae and very narrow digitiform glands in the female epigynum (Fig. 22).

Description. Male. Total length: 3.00. Carapace light brown variegated with dark brown, 1.80 long, 1.40 wide, 1.05 high, with a median dark brown stripe extending from between

Revista Brasileira de Zoologia 23 (2): 529-536, junho 2006 
the PLE to the posterior edge of the carapace. Ocular quadrangle 0.70 long. Anterior eye row 1.25 wide and posterior 1.17 wide. Cephalic region black, glabrous. Clypeus densely covered with white hairs. Chelicera yellow, with 5 teeth on promargin. Endite, labium and sternum yellow. Palp with long embolus; RTA with two short and separated branches, two spine-like setae on the dorsal branch and one on the ventral branch; VTA curved (Figs 19-20). Legs 4312 yellow, with light brown rings. Length of femur: I 0.85, II 0.85, III 0.80, IV 1.50; patella + tibia: I 0.95, II 0.95, III 0.95, IV 1.55; metatarsus + tarsus: I 0.85, II 0.80, III 0.95 , IV 1.30. Abdomen cream variegated with dark brown, dorsally covered by a dark brown scutum and with three pairs of cream spots. Anterior spinnerets cream, posterior brown.

Female. Total length: 3.55. Carapace dark brown, variegated, 1.90 long, 1.50 wide, 1.00 high. Ocular quadrangle 0.80 long. Anterior eye row 1.30 wide and posterior 1.25 wide. Carapace covered laterally with white hairs and long brown hairs around eyes. Clypeus densely covered with white hairs. Chelicera light brown, with 5 teeth on promargin. Endite and labium yellow, sternum light brown. Palp yellow with brown rings. Legs 4312 yellow, with dark brown rings. Length of femur: I 0.90, II 0.90, III 0.90, IV 1.75; patella + tibia: I 1.10, II 1.00, III 1.00, IV 1.95; metatarsus + tarsus: I 0.85 , II 0.85 , III 1.05, IV 1.50. Abdomen dark brown dorsally, with two pairs of pale spots, light brown laterally and ventrally. Epigynum with a small U-shaped atrium and a short septum; posterior border sulcated medially; internally with large, round spermathecae and very long digitiform glands (Figs 21-22). Anterior spinnerets cream, posterior light brown.

Variation. Ten males: total length: 2.75-3.25; carapace length: 1.60-1.80. Five females: total length: 2.95-3.60; carapace length: 1.70-1.90. The number of spine-like setae on the retrolateral tibial projection (or RTA) is not always conserved, as pointed out for the holotype of $A$. pinquidor (GALIANO 1987: 162). Most of the males of $A$. viripotens sp. nov. examined from the state of Tocantins presented three spine-like setae on the dorsal branch of the RTA, instead of the two present in the holotype (Figs 19-20). Some of the females examined presented an abdominal coloration pattern similar to that of the male, with three pairs of dorsal spots, and some had median chevrons extending dorsally from the center to the posterior edge of the abdomen.

Additional material examined. Brazil. Rondônia: Vilhena, 18 males, IX.1999, M.C. Carvalho leg. (IBSP 51401-51406, 51408-51412); Tocantins: Palmas, 6 males and 1 female, 20-
24.XI.2000 (IBSP 51415-51421); Porto Nacional, 2 males, 1823.III.2001 (IBSP 51424-51425); 3 males and 2 females, 16.VIII.2001 (IBSP 51422-51423, 51426-51427), all collected by I. Knysak \& R. Martins.

Distribution. Known from the states of Rondônia and Tocantins (Brazil).

\section{ACKNOWLEDGMENTS}

Thanks to CNPq (Conselho Nacional de Desenvolvimento Científico e Tecnológico) and FAPESP (Fundação de Amparo à Pesquisa do Estado de São Paulo, 99/05446-8) for the financial support. To G.B. Edwards and Cristina A. Rheims for suggestions on the manuscript. This study is part of the BIOTA/FAPESP - The Biodiversity Virtual Institute Program (www.biotasp.org.br) and was developed in the Programa de Pós-Graduação do Instituto de Biociências da Universidade de São Paulo.

\section{REFERENCES}

Galiano, M.E. 1987. Description of Aillutticus, new genus (Araneae, Salticidae). Bulletin of the British Arachnology Society, Dorset, 7:157-164.

GaLiano, M.E. 1989. Las especies de Sitticus del grupo leucoproctus (Araneae, Salticidae). Revista de la Sociedad Entomológica Argentina, San Miguel de Tucumán, 45: 257-269.

Galiano, M.E. 1991a. Las especies de Sitticus del grupo palpalis (Araneae, Salticidae). Acta Zoologica Lilloana, San Miguel de Tucumán, 40: 59-68.

Galiano, M.E. 1991b. Revisión del género Jollas (Araneae, Salticidae). Physis (C), Buenos Aires, 47: 15-29.

Platnick, N.I. 2006. The world spider catalog. Version 6.5, American Museum of Natural History, available online at http://research.amnh.org/entomology/spiders/catalog/ index.html [accessed in 11.V.2006]

RizzinI, C.T. 1997. Tratado de fitogeografia do Brasil. Rio de Janeiro, Âmbito Cultural Edições, $2^{\text {nd }}$ ed., 747p.

Ruiz, G.R.S. \& A.D. BRescovit. 2005. Three new genera of jumping spider from Brazil (Araneae, Salticidae). Revista Brasileira de Zoologia, Curitiba, 22 (3): 687-695.

Ruiz, G.R.S. \& A.D. Brescovit. 2006. Gavarilla, a new genus of jumping spider from Brazil, and description of two new species of the genera Capeta and Amatorculus (Araneae, Salticidae, Sitticinae). Revista Brasileira de Zoologia, Curitiba, 23 (2): 350-356.

Received in 17.VIII.2006; accepted in 16.V.2006. 